\title{
THE TEXT-BASED CHARACTER IN TEACHING READING COMPREHENSION AT THE TENTH GRADE STUDENTS
}

\author{
Like Raskova Octaberlina, Andi Asrifan, Nurlina \\ ${ }^{1}$ Universitas Islam Negeri Maulana Malik Ibrahim, Malang, Indonesia \\ 2,3Universitas Muhammadiyah Sidenreng Rappang
}

\begin{abstract}
The objective of this article was to find out whether or not using Text-based Character in Teaching Reading Comprehension.In this research, the researcher applied quasi experimental method using two groups namely an experimental and a control group. The population was the first-year students of SMA Negeri 4 Sidenreng Rappang in academic year 2019/2020. The total population is about 60 students. The sample of this research is selected by using cluster sampling techniques which is divided into two groups namely an experimental group and control one. The instrument was intended to measure the students' achievement of language skill particularly reading skill. The model of reading test is a objective test. Based on the reseach result, the researcher found that the mean score of pretest of experimental group was 72.67, it was classified into good classification and the mean score of students 'pretest of control group was 69.63, it was classified into good classification. After doing treatments, the result shows that the mean scores of both experimental and control group were different. The mean score of posttest for experimental group was 82.43 which was classified into very good classification and the mean score of control group was 76.53 which was classified into good classification. In other hand, the researcher found that the T-table is higher than $t$ test ( $\alpha)(1.659<2.021)$. It means that there is significant difference in pretest of control and experimental group, while in posttest of experimental and control group, the researcher find that the T-test is higher than alpha and previous score in pre-test $(\alpha)$ (3.089>2.021).The degree of freedom is 58.It means that there is significant difference in posttest. It indicates that the alternative hypothesis (H1) was accepted and the null hypothesis $(\mathrm{HO})$ was rejected. It can be concluded that the use of Text-based Character improves students' reading skill.
\end{abstract}

KEYWORDS: character, reading, teaching,

\section{INTRODUCTION}

Reading is a very important skill that students must master. If students are able to read well and get a good understanding, they can succeed and understand the 
entire section or paragraph given. Without understanding the reader does not really read. Students can read a lot of material that is suitable and interesting in it.

The act of reading cannot be separated from understanding. Students cannot achieve their academic success without understanding what they are reading. In understanding the text, students must be monitored by the teacher, so the way to teach understanding must be well understood by the teacher. Teaching understanding is an activity through several steps: selecting texts, explaining strategies, modeling strategies, supporting guidance, practicing independently, and reflecting. Therefore, it can be concluded that reading comprehension is a long process

Reading was an important activity for expanding knowledge of a language. By reading, students are able to master and know knowledge about certain subjects. They can catch what texts tell about. Also, they can learn the language because the texts provide the structures of the language to learn. Nunan (1991) stated that reading is usually conceived of as a solitary activity in which the reader interacts with the text in isolation. Thus, students try to understand the texts. It is needed because individual learning is sometimes effective for students.

In addition, through reading, students can recognize text. They can analyze detailed text information. They can also analyze structures related to text. In this learning students and teachers learn together. The teacher can teach the contents and structure of the text to students and on the other hand they pay attention to analyzing the text together with the teacher. The process of identifying written words is especially a concern of the teacher in early reading. Therefore, reading is an activity to get information in written language. Readers can get information for their needs. This can support their learning to master the language, so reading is a useful activity to expand knowledge.

One of the challenges for educators today is that children continue to be confronted with violence, sarcasm, and neglect of human dignity by watching too much television and other media (Lickona, 1991). It's easy to see where their negative behavior is coming from. Students need social skills to participate in the most commonly used learning activities in the classroom (McArthur, 2002). One problem faced by alternative school educators is that many students come to these programs with little socially acceptable values and morals and lack of imperfect social skills (Gathercoal, \& Crowell, 2000).

Marwin (2007) states that Character education is a national movement that creates schools that foster ethical, responsible and caring young people by modeling and teaching character through an emphasis on universal values that we all share. This is a deliberate proactive effort by schools, districts and states to instill ethical values in their core students such as caring, honesty, fairness, responsibility, and respect for themselves and others

Using text-based character education can also emphasize improving students' communicative abilities, namely the ability to get good achievements for English subjects, students need perseverance and patience in learning them because most students find difficulties in these subjects, especially in learning to read with 
communicative. approach. In this case students are expected to have a hobby of reading and communicative practice. That is why teacher assistance is needed to improve their performance.

Based on the curriculum center of the national education ministry's research and development body in the title guidelines for the implementation of character education (2011), it was identified that there are 18 characters that make up the following values:

1. Religious : Attitudes and behaviors that are obedient in carrying out the teachings of their religion, are tolerant of the implementation of worship of other religions, and live in harmony with followers of other religions.

2. Honest: Behavior that is based on efforts to make himself as a person who can always be trusted in words, actions, and work.

3. Tolerance: Attitudes and actions that respect differences in religion, ethnicity, ethnicity, opinions, attitudes, and actions of others are different from those of themselves.

4. Discipline : Actions that show orderly behavior and adhere to various rules and regulations.

5. Hard work : Behavior that shows genuine effort in overcoming various obstacles and completing tasks as well as possible.

6. Creative : Thinking and doing something to produce new ways or results from something that already has.

7. Independen : Attitudes and behaviours that are not easily dependent on others in completing tasks and various other activities.

8. Democratic : How to think, behave, and act that assesses the rights and obligations of himself and others.

9. Curiosity :Attitudes and actions that always strive to know more deeply and extensively from something they learn, see, and hear.

10. Spirit of nationality : The way to think, act, and be insightful that places the interests of the nation and the state above the interests of themselves and their groups.

11. Love the Motherland : How to think, behave, and behave that shows a sense of loyalty, caring and high appreciation for the language, physical, social, cultural, economic, and political environment of the nation.

12. Appreciating Achievements : Attitudes and actions that encourage him to produce something useful for the community, and recognize, and respect the success of others.

13. Friendly / Communicative: Attitudes and actions that encourage themselves to produce something useful for the community, and recognize, and respect the success of others.

14. Love of Peace : Attitudes and actions that encourage themselves to produce something that is useful for the community, and recognize, and respect the success of others.

15. Like to read: Habits provide time to read various readings that provide virtue for him. 
16. Care for the Environment: Attitudes and actions that always strive to prevent damage to the surrounding natural environment, and develop efforts to repair natural damage that has occurred.

17. Social Care : Attitudes and actions that always want to provide assistance to other people and the people in need.

18. Responsibility: The attitude and behavior of a person to carry out their duties and obligations, which he must do, towards oneself, society, environment (natural, social and cultural), the state and God Almighty.

There are some relevant previous related to this study. Some of their findings we as follow:The first research was done by Mohammed Al-Mamun Abd Al-Magid (2006) in entitled Effects of Teacher Attitudes on Effective Implementation of Communicative Approaches in Esl Classes. The findings show that effective implementation of the communicative approach is highly dependent on the teacher's positive attitude towards this approach in the five categories covered by his research.

Next Noer Doddy Irmawati entitled Alternative Methods Used in Improving Student Academic Reading Achievement (2012). The results of his study showed that the application of the communicative approach effectively improved students' ability to read academic students at the Faculty of Literature, UAD Yogyakarta. It can be seen from the improvement of several aspects, (1) aspects of reading ability, (2) aspects of English: vocabulary, grammar, pronunciation, communication, and ability to work together, collaboration, socialization, sharing ideas, opinions, and suggestions. Teaching objectives, syllabus models, forms of teaching and learning activities, and types of learning materials used by teachers are consistent with those recommended by communicative approaches. In addition Rudiyanto (2011) in entitled Teaching Reading Comprehension Using Communicative Approach Through Songs And Games To The Eigth Year Students Of SMP. State that communicative approach through songs and games has important role in teaching reading achievement, but the researcher still pay attention to the role of the other important manner, such as library and students creation. So that, it was clear that communicative approach teaching method, reading and practice communication will grow learners' interest of the success in learning reading achievements process.

In similar works Tessema (2012) in entitled The Role of Instructors in Implementing Communicative Language Teaching Methodology concluded that research results gathered through three tools reveal that because there is a lack of upto-date teaching materials, the lack of experience on the part of the instructor and the problem of using different active learning methods to apply communicative approaches effectively and efficiently in their teaching-learning process. Moreover, Reading comprehension in the English context as a second language becomes a very important lesson and much needed by students and therefore reccomended teacher to prepare reading summarizing to help them improve their reading comprehension (Nasrin Khaki:2014) in entitled "Improving Reading Comprehension in a Foreign Language: Strategic Reader”. 
From the cited research findings above, Researchers are interested in knowing the application of the communicative approach in learning to read in common with all the researchers above who use communicative as an approach. Furthermore, this approach supports and assists students in understanding about their reading because students sometimes have difficulty reading and also to understand the contents of the text.

\section{METHOD}

\section{Research design}

The method used was In this research, the researcher applied quasi experimental method using two groups namely an experimental and a control group. The experimental group received treatment by using text-based character, while the control group received conventional technique where the students were asked to do exercises and some reading activities based on the topic given by the teacher. Both of groups were given pretest and posttest. The pretest was given to find out the students' basic achievement in writing and posttest was given to find out the effectiveness of using text-based character in teaching reading comprehension.

\section{Variable nof the research}

There are two variables in this research namely independent variable (X) and dependent variable (Y). The independent variable is the use of text-based character education, and the dependent variable is the student's reading comprehension.

\section{Population and sample}

According to (Creswell:2012) state that a population is a group of individuals who have the same characteristic.

The population of this research is the tenth Grade students of SMAN 4 sidrap. There are three classes, where X MIPA.1 to X MIPA 3. in addition, the total of population are 90 students.

Table 1 The Students Population of X Grade of SMAN 4 SIDRAP

$\begin{array}{lcc}\text { No } & \text { Class } & \text { Students } \\ 1 & \text { X MIPA 1 } & 32 \\ 2 & \text { X MIPA 2 } & 30 \\ 3 & \text { X MIPA 3 } & 30 \\ & \text { TOTAL } & 92\end{array}$

According to Ary (2009) stated that this type of probability sampling is referred to as cluster sampling, systhematic sampling, stratified sampling, random sampling. The researcher choose cluster sampling because the selected unit is not an individual but a group of individuals who are naturally together. The researcher used a cluster sampling technique to select classes, where one whole class will be sampled. In this research used narrative text, so that researcher choose class $\mathrm{X}$ because the narrative text included in learning material of class X. Used cluster random sampling technique that two class would be the samples. Where X MIPA 3 was an experimental class which consists of 30 students and X MIPA 2 was a 
control Class which consist of 30 students, so the total numbers of sample is 60 students.

\section{Instrument of the research}

The instrument would use in this study is the instrument shape test reading comprehension according (Heaton:1990).

Reading comprehension test form:
a. word/sentence matching,
b. multiple choice,
c. true/false test,
d. completion items,
e. cloze procedure,
f. open-ended and miscellaneous items,
g. cursory reading.

\section{Procedure of collecting data}

The procedure of the researchinvolves the following steps:

1. Pre-test

Before conducting the treatment, this research administeres the pre-test to the students. It aims to identifying the students' reading comprehension. In the class, the researcher give some text to read. This type of reading test is the researcher provides a narrative text and asked to choose the most correct answer from the given option. The total amount of the questions is 30 items.

2. Treatment

a. The researcher explained how the learning process will going on.

b. The researcher prepares a teks and distribute it to students.

c. Giving a times (5-8 seconds) or as needed to students to do an observation.

d. Asking indicator questions or competency to the students that would be achieve.

e. Asking student some answers related to the topic

f. Giving a times (3-5 seconds) to provide an opportunity to students search for answers.

g. Asking last questions to students to further confirm that the target of basic competencies already achieve and how the influence to their character.

h. Providing additional information for students to answer.

i. After all the process, the researcher will give the students comprehension about the activity and ask their suggestion and commentary about the learning process so that each meeting can be more effective and fun between the researcher and the students, the which is related to treatment.

3. Post-test

After giving treatment, this research would give the students post-test to find out the students' comprehension in reading through text-based character education. The kind of reading test is the researcher give a narrative text and asked to choose the most correct answer from the given option consist on 15 
numbers, completion the items consist on 5 numbers and true/false consist on 5 numbers and essay 5 numbers. The total amount of the questions is 30 items.

\section{Technique of Data Analysis}

To analyze the data that collected from the pre-test and post-test, the following formula used in this research, they are:

Points for students' answer the researcher use the following formulas:

Table 2 Multiple choice test,true false and copletion items

$\begin{array}{cc}\text { Indicator } & \text { Score } \\ \text { Correct } & 1 \\ \text { Incorrect } & 0\end{array}$

(DirjenPendidikanDasardanMenengah 2005)

Scoring the students' answer:

$$
\text { Score : } \frac{\text { The students'gained scores }}{\text { maximun scores }} \times 100
$$

(DirjenPendidikanDasardanMenengah 2005)

To measure the quality of the students' writing score on five components observed, the data are classified into five classifications by referring the classification of system score that used at SMA Muhammadiyah Rappang as follows:

80 to $100(4)$ is classified as "very good" or " $\mathrm{A}$ ".

70 to 79 (3) is classified as "good" or "B".

60 to $69(2)$ is classified as "average" or " $\mathrm{C}$ ".

50 to 59 (1) is classified as "poor" or " $\mathrm{D}$ ".

0 to $49(0)$ is classified as "very poor" or " $E$ ".

(Depdiknas, 2006)

Calculating the mean score, standard derivation, frequency table, and the value of pvalue to identify the difference between pre-test and post-test by using inferential analysis in SPSS program for Windows evaluation version.

Criteria of testing hypothesis

1. If $p$. value $>0,05=\mathrm{H}_{0}$ would be accepted, $\mathrm{H}_{1}$ would be rejected. It means that there was no significance difference between the pre test and post test.

2. If $\mathrm{p}$. value $<0,05, \mathrm{H}_{1}$ would be accepted, $\mathrm{H}_{\mathrm{O}}$ would be rejected. It means that there was a significance difference between the pre test and post test.

\section{RESULT AND DISCUSSION}

Scoring classification of the students' pretest in experimental and control group. 
Students' scores of pretest are classified into five classifications based on the classification system that used at SMA Negeri 4 Sidrap. These classifications are very good (80-100), good (70-79), average (60-69), poor (50-59), and very poor (049). The frequency and the rate percentage of the students' score of pretest in experimental and control group are presented in the following:

Table 3. The rate percentage and frequency of students' scores of pretest in experimental and control group

\begin{tabular}{llllll} 
Classification & Score & \multicolumn{2}{c}{ Experimental Group } & \multicolumn{2}{c}{ Control Group } \\
Very good & $80-100$ & 3 & 10 & 1 & \% \\
Good & $70-79$ & 18 & 60 & 14 & 47 \\
Average & $60-69$ & 8 & 27 & 12 & 40 \\
Poor & $50-59$ & 1 & 3 & 3 & 10 \\
Very poor & $0-49$ & 0 & 0 & 0 & 0 \\
Total & & $\mathbf{3 0}$ & $\mathbf{1 0 0}$ & $\mathbf{3 0}$ & $\mathbf{1 0 0}$
\end{tabular}

This table shows that the pretest result of experimental group is 3 students $(10 \%)$ were classified into very good classification, 18 students $(60 \%)$ were classified into good classification, 8 students $(27 \%)$ classified into average classification, 1 student (3\%) was classified into poor classification and none of the students ( $0 \%$ ) classified into very poor classification. The pretest result of control group is 1 student (3\%) classified into very good classification, 14 students (47\%) classified into good classification, 12students $(40 \%)$ were classified into average classification, 3 students $(10 \%)$ were classified into poor classification and none of the students $(0 \%)$ classified into very poor classification.

Table 4 . The rate percentage and frequency of students' scores of posttest in experimental and control group.

\begin{tabular}{|c|c|c|c|c|c|}
\hline \multirow{2}{*}{ Classification } & \multirow{2}{*}{ Score } & \multicolumn{2}{|c|}{ Experimental Group } & \multicolumn{2}{|c|}{ Control Group } \\
\hline & & $\mathbf{F}$ & $\%$ & $\mathbf{F}$ & $\%$ \\
\hline Very good & $80-100$ & 18 & 60 & 15 & 50 \\
\hline Good & $70-79$ & 12 & 40 & 11 & 37 \\
\hline Average & $60-69$ & 0 & 0 & 3 & 10 \\
\hline Poor & $50-59$ & 0 & 0 & 1 & 3 \\
\hline Very poor & $0-49$ & 0 & 0 & 0 & 0 \\
\hline
\end{tabular}




\section{Total}

This table shows that after giving the treatments, the experimental group showed the improvement in posttest. It can be seen in data which was presented in table 3. It shows that 12 students $(40 \%)$ were categorized into good category, 18 students $(60.0 \%)$ were categorized into good category and none of the students $(0 \%)$ got average, poor and very poor classification. The improvement of control group can be shown by the result of students' posttest. 1 student (3\%) got poor score classification, 3 students (10.0\%) got average score classification, 11 students (37\%) got good score classification and 15 students $(50 \%)$ got very good score classification.

The comparison between the students' scores of pretest in experimental and control group.

Table 5. The mean score and standard deviation of the students' pretest score.

$\begin{array}{llll}\text { Group } & \text { Sample } & \text { Mean Score } & \begin{array}{l}\text { Standard } \\ \text { Deviat }\end{array} \\ \text { Experimental } & 30 & 72.67 & 6.172 \\ \text { Control } & 30 & 69.63 & 7.889\end{array}$

This table shows that the mean score of students' pretest of experimental group was 72.69 and the mean score of students' pretest of control group was 69.63. Both groups were classified into good classification in range 70-79.

Table 6 . The mean score and standard deviation of the students' posttest score.

\begin{tabular}{llll} 
Group & Sample & Mean Score & $\begin{array}{l}\text { Standard } \\
\text { Deviation }\end{array}$ \\
\hline Experimental & 30 & 82.43 & 6.140 \\
Control & 30 & 76.53 & 8.472
\end{tabular}

This table shows that the mean score of students' posttest in experimental group was 82.43 which classified into very good classification and the mean score of students' posttest in control group was 76.53 which was classified into good classification.

Test of significance (t-test) of reading achievement on control and experimental group.

The hypotheses were tested by using inferential analysis. In this case, the researcher used t-test (test of significance) for independent sample test. It is a test to know the significant difference between the result of students' scores in pretest and posttest in control group and experimental group. The level of significance $(0.05)$ with degrees of freedom $\mathrm{df}=\mathrm{n} 1+\mathrm{n} 2-2$, where $\mathrm{n}=$ number of subject (30). The following table shows the result of the calculation.

Table 7. t-test of reading achievement on control group and experimental group.

Variable T-test T-table


Pretest of experiment and

Control group

Posttest of experiment and control 3.089 group

This table shows that the T-tablewas higher than t-test $(\alpha)(1.659<2.021)$. It indicated that there was no significant difference in pretest, while in posttest of control and experimental group, the researcher found that the t-test was higher than t-table $(\alpha)$ and the result of post-test (3.089>2.021) and the degree of freedom 58. It showed that there was significant difference in posttest. It can be concluded that the null hypothesis $\left(\mathrm{H}_{1}\right)$ was accepted and the alternative hypothesis $\left(\mathrm{H}_{0}\right)$ was rejected. It means that the use of text-based character improve students' reading comprehension skill. Based on previous findings on, the researcher analyzed that before treatment, the mean score of pretest of experimental group was 72.67. It was classified into good classification and the mean score of students 'pretest of control group was 69.63. It was classified into good classification. Gay (2006:124) states that the difference between close score is essentially the same to the students. The mean score between experimental and control group was relatively the same. Both experimental and control group have the same baseline knowledge in reading skill before the treatment. They were at good classification.

After doing treatments, the result shows that the mean scores of both experimental and control group were different. The mean score of posttest for experimental group was 82.43 which was classified into very good classification and the mean score of control group was 76.53 which was classified into good classification. Furthermore, the standard deviation for experimental group was 6.140 and control group was 8.472. The experimental group was in "very good" and the control group was still in "good" category. Sainu (1998:22) sates that short story reading is useful to encourage students to write intensively. It means that using literature in the classroom can improve students' reading achievement.

To know whether or not the means are significantly different, the researcher used t-test in inferential statistic through SPSS version 21.0 program to test the hypothesis. In pretest between experimental and control group, the researcher found that the T-able is higher than t-table $(\alpha)(1.659<2.021)$. It means that there is significant difference in pretest of control and experimental group, nevertheless it was a little bit significant, while in posttest of experimental and control group, the researcher find that the T-test is higher than alpha and privious score in pre-test $(\alpha)$ (3.089> 2.021).The degree of freedom is 58.It means that there is significant difference in posttest. It indicates that the alternative hypothesis $\left(\mathrm{H}_{1}\right)$ was accepted and the null hypothesis $\left(\mathrm{H}_{0}\right)$ was rejected. It can be concluded that the use of textbased character improves students' reading skill.

\section{CONCLUSION}

The researcher found that the mean score of pretest of experimental group was 72.67. It was classified into good classification and the mean score of students 
'pretest of control group was 69.63. It was classified into good classification. After doing treatments, the result shows that the mean scores of both experimental and control group were different. The mean score of posttest for experimental group was 82.43 which was classified into very good classification and the mean score of control group was 76.53 which was classified into good classification. Furthermore, the standard deviation for experimental group was 6.140 and control group was 8.472. The experimental group was in "very good" and the control group was still in "good" category.

In other hand, the researcher found that the T-table is higher than t-test $(\alpha)$ $(1.659<2.021)$. It means that there is significant difference in pretest of control and experimental group, while in posttest of experimental and control group, the researcher find that the T-test is higher than alpha and previous score in pre-test $(\alpha)$ (3.089 > 2.021).The degree of freedom is 58. It means that there is significant difference in posttest. It indicates that the alternative hypothesis (H1) was accepted and the null hypothesis ( $\mathrm{H} 0)$ was rejected. It can be concluded that the use of textbased character improve students' reading skill.

\section{REFERENCES}

Abd Al-magid, Mohammed al-Mamun. 2006. The Effect of Teacher's Attitude on The Effective Implementation of The Communicative Approach in Esl Classroom. University of South Africa.

Ary, Donald., Jacobs, C Lucy., Sorensen, K Christine. 2010. Introduction To Research In Education Eighth Edition. Belmont, Ca 94002-3098. Usa

Creswell, W.John. 2012. Educational Research Planning, Conducting And Eavluating Quantitative And Qualitative Research. Pearson Education. Boston.

Dirjen Pendidikan Dasar dan Menengah. 2005

Deputi Pendidikan Nasional. 2006

Heaton, J.B. 1991. Writing English Language Testing. London: Longman

Irmawati, Noer Doddy. 1999. Communicative Approach: An Alternative Method Used in Improving Students' Academic Reading Achievement. Yogyakarta: Faculty of Postgraduate Study \& Faculty of Letters, Ahmad Dahlan University.

Jensen, Melissa. 2010. Improving Reading Comprehension Of Junior Division Students As The Teacher-Librarian: An Action Research Study Submitted In Partial Fulfillment Of The Requirements For The Degree Of Master Of Education Nipissing University Faculty Of Education. North Bay: Ontario.

Khaki, nasrin. 2014. Improving reading comprehension: the role of visual mind mappingin SQ4R strategy.

Lickona, Thomas.1991.educating for character. New York.

Nunan, d. 1991. Language teaching methodology A textbook fo teacher.

Raka Joni, T. 1998. Penelitian Tindakan Kelas: Beberapa Permasalahannya. Jakarta: PCP PGSM Dirjen Dikti. 
Rudiyanto. 2011. Teaching Reading Comprehension Using Communicative Approach Through Songs And Games To The Eigth Year Students Of SMP. Jakarta: UIN syarif Hidayatullah.

The National Education Ministry's Research and Development. 2011. Guidelines for the Implementation of Character Education.

Tessema,M., Ready, K., \& Malone,C. 2012. Effect of gender on college students satisfaction and achievment the case of a midsized midwestern public university.

Asrifan, A. (2009). Using songs in teaching English language for the young learners. ParePare: unpublished.

Puasa, K., Asrifan, A., \& Chen, Y. (2017). Classroom Talk in Bilingual Class Interaction. Research in Pedagogy, 7(1), 106-121.

Nadirah, N., Tahir, M. H., \& Asrifan, A. (2019). THE ABILITY TO TRANSLATE ENGLISH PHRASES INTO INDONESIAN AND THE DIFFICULTIES FACED BY THE ELEVENTH GRADE STUDENTS OF SMAN 1 PANCARIJANG. JOURNAL OF ADVANCED ENGLISH STUDIES, 2(1), 41-46.

Apdy, A. P. R., \& Asrifan, A. (2019, April). The Chinese mime game in teaching vocabulary on EFL classroom. In PROCEEDINGS OF THE 65th TEFLIN INTERNATIONAL CONFERENCE (Vol. 65, No. 01).

Taslim, T., Asrifan, A., Chen, Y., \& Nurdania, N. R. (2019). CORRELATION BETWEEN STUDENT'S VOCABULARY MASTERY AND SPEAKING SKILL. JOURNAL OF ADVANCED ENGLISH STUDIES, 2(2), 65-76.

Muthmainnah, M., Asrifan, A., Al Yakin, A., \& Sahabuddin, C. (2019, April). The use of dictogloss technique on ELT classroom: An experiment study of students listening comprehension. In PROCEEDINGS OF THE 65th TEFLIN INTERNATIONAL CONFERENCE (Vol. 65, No. 01).

Mutmainnah, M., Azis, S., Maulidya, U., \& Asrifan, A. (2017). Glory Style in Mandar Song Lyrics: A study of Mandar Tribe in South Sulawesi, Indonesia. JOURNAL OF ADVANCES IN LINGUISTICS, 8(1), 12861291.

Asrifan, A., Rinantanti, Y., Tang, S., \& Nadirah, N. (2019). THE 3-DIMENSION PICTURES IN INCREASING THE STUDENTS ABILITY AND INTEREST TO WRITE DESCRIPTIVE COMPOSITION. JOURNAL OF ADVANCED ENGLISH STUDIES, 2(1), 19-30.

Asrifan, A., Nadira, N., \& Haedar, H. (2018). IMPROVING STUDENTS'READING COMPREHENSION OF DESCRIPTIVE TEXT THROUGH COLLABORATIVE MURDER. JOURNAL OF ADVANCED ENGLISH STUDIES, 1(2), 21-31.

Asrifan, A. (2015). Analysis of English Students' Learning Style in Bilingual Class. International Journal of Literature and Arts, 3(4), 34. 
Farahdiba, S., \& Asrifan, A. (2016). Speaking Ability and Psychological Barriers of the Second Year Students of Hotel Department of SMKN 1 Sidenreng Kabupaten Sidrap in Speaking English. Asian EFL Journal, (89), 41.

Asrifan, A. (2012). Increasing the Students Ability to Write Descriptive Composition at SMP Negeri 13 Parepare by using the 3-Dimension Pictures.

Tang, S., Asrifan, A., Chen, Y., Haedar, H., \& Agussalim, M. (2019). THE HUMOR STORY IN TEACHING READING COMPREHENSION. JOURNAL OF ADVANCED ENGLISH STUDIES, 2(2), 77-87.

Nurwanti, N., Asrifan, A., \& Haedar, H. (2019). THE APPLICATION OF COOPERATIVE LEARNING: JIGSAW II TECHNIQUE IN IMPROVING STUDENTS'READING COMPREHENSION OF EXPOSITORY TEXT. JOURNAL OF ADVANCED ENGLISH STUDIES, 2(1), 31-40.

Asrifan, A. (2016). The Effectiveness of Think-Pair-Share Technique in Improving Studentsâ€TM Speaking Ability and Interest. English Literature and Language Review, 2(3), 24-35.

Asrifan, A., Muthmainnah, M., Al-Yakin, A., Sahabuddin, C., \& Haedar, H. (2018). THE CAUSE-EFFECT TECHNIQUE IN TEACHING RECOUNT WRITING. JOURNAL OF ADVANCED ENGLISH STUDIES, 1(2), 63-72.

Asrifan, A., Vargheese, K. J., Syamsu, T., \& Amir, M. (2020). ESP COURSE DESIGN: THE NEED ANALYSIS ON TOURISM DEPARTMENT IN INDONESIA VOCATIONAL HIGH SCHOOLS. JOURNAL OF ADVANCED ENGLISH STUDIES, 3(2), 69-77.

Asrifan, A., Ghofur, A., \& Azizah, N. (2020). Cheating Behavior in EFL Classroom (A Case Study at Elementary School in Sidenreng Rappang Regency). OKARA: Jurnal Bahasa dan Sastra, 14(2), 279-297.

Nadirah, N., Asrifan, A., Vargheese, K. J., \& Haedar, H. (2020). INTERACTIVE MULTIMEDIA IN EFL CLASSROOM: A STUDY OF TEACHING READING COMPREHENSION AT JUNIOR HIGH SCHOOL IN INDONESIA. JOURNAL OF ADVANCED ENGLISH STUDIES, 3(2), 131-145.

Muthmainnah, A. R., Atmowardoyo, H., Salija, K., \& Asrifan, A. (2020). Literary Work as Teaching Materials: A Study of Students and Lecturers Needs Analysis. Solid State Technology, 63(5), 394-407.

Tilome, A. A., Agustang, A., Jasruddin, M. S., \& Asrifan, A. (2020). Social Exchange of Political Elites in the Regional Leader Election of Gorontalo Province, Indonesia. Solid State Technology, 63(5), 521-531.

Pacinongi, A., \& Asrifan, A. (2020). Bimbingan Pengawas Berkelanjutan dalam Mewujudkan Pendidikan Karakter Bangsa dalam Kegiatan Belajar Mengajar Penjaskes. Celebes Education Review, 2(1), 1-7. 
Gunawan, G., \& Asrifan, A. (2020). Penerapan Kerja Kelompok Kegiatan MGMP Guru Ekonomi dalam Menyusun RPP untuk Meningkatkan Kompetensi Pedagogik. Celebes Education Review, 2(1), 31-36.

Yusuf, I., \& Asrifan, A. PENINGKATAN AKTIVITAS KOLABORASI PEMBELAJARAN FISIKA MELALUI PENDEKATAN STEM DENGAN PURWARUPA PADA SISWA KELAS XI IPA SMAN 5 YOGYAKARTA. Editorial Team, 32.

Al Yakin, A., Sahabuddin, C., Rahayu, A., Fitrah, N., \& Arifin, M. (2020). Political Celebrification and Electability: A Study of Political Phenomena Imaging in Election Polewali Mandar District, West Sulawesi, Indonesia. Solid State Technology, 63(5), 632-646.

Junaedah, S. B. T., \& Ahmad, M. A. (2020). The Outdoor Learning Modules Based on Traditional Games in Improving Prosocial Behaviour of Early Childhood. International Education Studies, 13(10).

Octaberlina, L. R., \& Muslimin, A. I. (2020). Efl students perspective towards online learning barriers and alternatives using moodle/google classroom during covid-19 pandemic. International Journal of Higher Education, 9(6), 1-9.

Octaberlina, L. R., \& Anggarini, I. F. (2020). Teaching vocabulary through picture cards in Islamic Elementary School: a case study in Nida Suksa School, Thailand. Jurnal Madrasah, 13(1), 26-38.

Octaberlina, L. R. (2016). Plagiarism in English language theses in Indonesia. Jurnal Ilmu Pendidikan, 14(3).

Octaberlina, L. R., \& Anggarini, I. F. (2020). Teaching vocabulary through picture cards in Islamic Elementary School: a case study in Nida Suksa School, Thailand. Jurnal Madrasah, 13(1), 26-38.

Octaberlina, L. R., Anggarini, I. F., \& Muslimin, A. I. (2020). Virtual English teaching in remote area: a case study. Journal of Critical Reviews, 7(19), 9707-9713.

Amalia, L. L. (2019). REFLECTIVE PRACTICE AND SELF-IDENTITY AS PARTS OF PROFESSIONAL DEVELOPMENT: A SURVEY IN A TERTIARY LEVEL. E-Link Journal, 6(1), 160-163.

Asrifan, A., Zita, C. T., Vargheese, K. J., Syamsu, T., \& Amir, M. (2020). THE EFFECTS OF CALL (COMPUTER ASSISTED LANGUAGE LEARNING) TOWARD THE STUDENTS'ENGLISH ACHIEVEMENT AND ATTITUDE. JOURNAL OF ADVANCED ENGLISH STUDIES, 3(2), 94-106.

Asrifan, A. (2021). ACADEMIC WRITING. LawArXiv. January, 2. https://doi.org/10.31228/osf.io/x2s7e

Asrifan, A. (2020). TUTORIAL PENGGUNAAN QUIZIZZ (www. quizizz. com) PADA PEMBELAJARAN. https://doi.org/10.31219/osf.io/kqnza

Asrifan, A. (2021). Abd Ghofur.“. THE USE OF READING CIRCLES IN INCREASING STUDENTS SPEAKING ABILITY AT THE ELEVENTH GRADE SMK NEGERI, 1. https://doi.org/10.31219/osf.io/8vjxy 
Asrifan, A. (2020). Pandemic, Humanity and Education. https://doi.org/10.31219/osf.io/q2gpk

Asrifan, A. (2021). USING CAT AND MOUSE GAME TO IMPROVE STUDENT'S SPEAKING ABILITY AT THE ELEVENTH GRADE OF MA YMPI RAPPANG. https://doi.org/10.31219/osf.io/phtvn

Asrifan, A., \& Ghofur, A. (2021). THE USE OF READING CIRCLES IN INCREASING STUDENTS SPEAKING ABILITY AT THE ELEVENTH GRADE SMK NEGERI 1 PANCARIJANG. https://doi.org/10.31219/osf.io/8vjxy

Asrifan, A. (2021). Book Review: Halliday. 1989. Spoken and Written Language. Oxford University Press. https://doi.org/10.31219/osf.io/ej8tb

Asrifan, A., \& Ghofur, A. (2021). TALK, ACTION, SILENCE, INTERRUPTION AND THEIR IMPLICATIONS IN BUGINESE SOCIETY (SOPPENG REGENCY). https://doi.org/10.31219/osf.io/pv3ku

Asrifan, A. (2020). PENILAIAN BERBASIS ANDROID MENGGUNAKAN APLIKASI PLICKERS. https://doi.org/10.31219/osf.io/htreq 